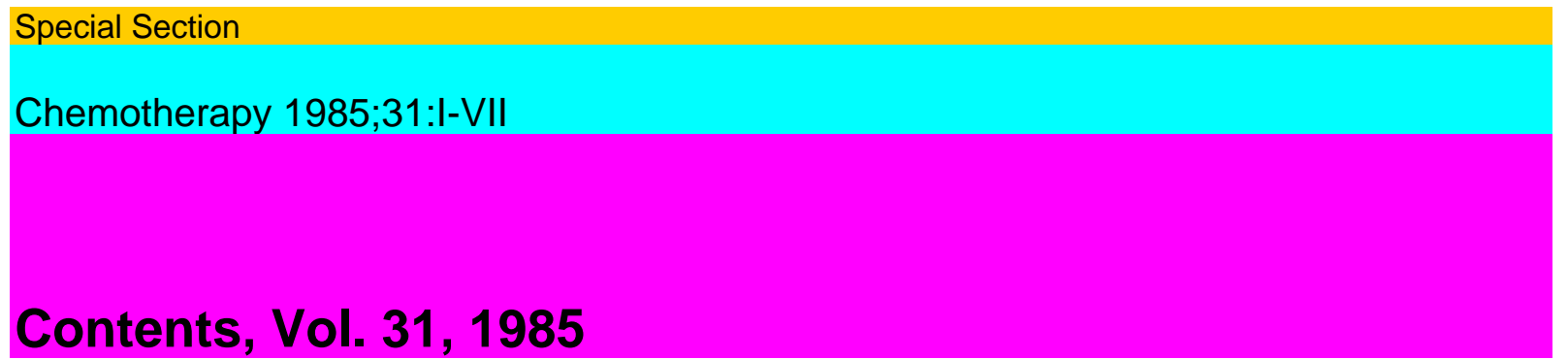

\title{
Vol. 31, 1985
}

Chemotherapy

International Journal of Experimental and Clinical Chemotherapy

Founded 1959 as 'Chemotherapia'

litor

Editorial Board

H. Schonfeld, Grenzach

T. Bergan, Oslo

W.P. Boger, Wayne, Pa.

L. Dettli, Basel

E.R. Garrett, Gainesville, Fla.

A. Goldin, Bethesda, Md.

H.E. Kaufman, New Orleans, La

P. Preziosi, Roma

R.W. Sidwell, Logan, Utah

W.H. Traub, Homburg/Saar

$\mathrm{mm}$

S. Karger $\bullet$ Medical and Scientific Publishers

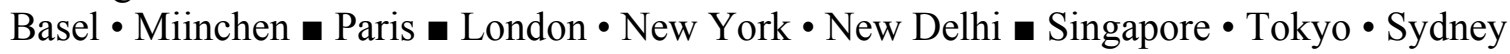

Drug Dosage

The authors and the publisher have exerted every effort to ensure that drug selection and dosage set forth in this text are in accord with current recommendations and practice at the time of publication. However, in view of ongoing research, changes in government regulations, and the constant flow of information relating to drug therapy and drug reactions, the reader is urged to check the package insert for each drug for any change in indications and dosage and for added warnings and precautions. This is particularly important when the recommended agent is a new and/or infrequently employed drug.

All rights reserved.

No part of this publication may be translated into other languages, reproduced or utilized in any form or by any means, electronic or mechanical, including photocopying, recording, 
microcopying, or by any information storage and retrieval system, without permission in writing from the publisher or, in the case of photocopying, direct payment of a specified fee to the Copyright Clearance Center (see 'Information for Readers and Subscribers').

(C) Copyright 1985 by

S. Karger AG, P.O. Box, CH-4009 Basel (Switzerland) Printed in Switzerland by Buchdruckerei Basler Zeitung, Basel

Contents Vol. 31,1985

No. 1 Pharmacology

Placental Transfer of Cefmenoxime in Late Pregnancy

Bergogne-Berezin, E.; Bryskier, A.; Berthelot, G.; Ravina, J.H.; Vernant, D 1

Cefoperazone Therapy of Complicated Urinary Tract Infections: Pharmacokinetics in Renal

Transplant Recipients

Goldstein, E.J.C.; Gombert, M.E.; Sierra, M.F.; Butt, K.M.H 6

Ciprofloxacin Distribution in Prostatic Tissue and Fluid following Oral Administration

Boerema, J.B.J.; Dalhoff, A.; Debruyne, F.M.Y 13

Microbiology

Comparative Evaluation of Recently Developed Quinolone Compounds - with a Note on

the Frequency of Resistant Mutants

Cullmann, W.; Stieglitz, M.; Baars, B.; Opferkuch, W 19

Infection with Clindamycin-Resistant Bacteroides uniformis

Zar, F.A.; Bond, E.J 29

Incomplete Cross-Resistance of Nalidixic and Pipemidic Acid-Resistant Variants of Serratia marcescens Against Ciprofloxacin, Enoxacin, and Norfloxacin

Traub, W.H 34

Experimental Chemotherapy

Chemotherapy of Systemic Murine Infection Due to (3-Lactam Antibiotic 'Tolerant' and

non-'Tolerant' Staphylococcus aureus

Traub, W.H 40

Response of a 'Susceptible' Escherichia coli to Metronidazole Therapy: An Investigation

Using Experimental Subcutaneous Abscesses

Reznikov, M.; Hakendorf, P.H.; Matthews, D.B 50

Antitumour Activity of Some Platinum Compounds

Chakraborty, B.K.; Biswas, N.; Choudhury, K.; Neogy, R.K.; Das Sarma, B

Treatment of the Rabbit V-2 Carcinoma with Intralesional Cisplatin

Wright, K.C.; Carrasco, C.H.; Wallace, S.; Stephens, L.C 60

Clinical Reports

Effect of a New Sulfa-Trimethoprim Combination (Trimethoprim-Sulfamethopyrazine) in

Thyroid Fever. A Double-Blind Study on 72 Adult Patients

Schiraldi, O.; Sforza, E.; Piaia, F 68

Antibiotic Infection Prophylaxis in Gallbladder Surgery - A Prospective Randomized

Study

Harnoss, B.-M.; Hirner, A.; Kruselmann, M.; Haring, R.; Lode, H 76

Book Reviews

83

IV Contents

No. 2 Pharmacology 
Pharmacokinetics of Ceftriaxone and Its Relation to Concentrations in Extra vascular Com partments. Comparison with Cefotaxime

Regamey, C 85

Microbiology

The Clover-Leaf Test and Inactivation of p-Lactam Antibiotics by Gram-Negative Rods Jorgensen, P.E 95

Latamoxef in Combination with Aminoglycosides against Pseudomonas aeruginosa: Simi larity with Ticarcillin

Sears, S.D.; Tatem, B.A.; Standiford, H.C 102

In vitro Antibacterial Activity of Norfloxacin and Other Agents against Ocular Pathogens

Shungu, D.L.; Tutlane, V.K.; Weinberg, E.; Gadebusch, H.H

Divergent Disk Susceptibility of Coagulase-Negative Staphylococci to Penicillinase-Resistant Penicillins and Augmentin (Amoxycillin/Clavulanic Acid)

Traub, W.H 119

In vitro Effects of the Combination of Nitrofurantoin and Trimethoprim against Sensitive and Nitrofurantoin and Trimethoprim-Resistant Escherichia coli K12

Obaseiki-Ebor, E.E 124

Comparative in vitro Activity of Ceftriaxone against Clinical Bacterial Isolates in Nigeria

Obaseiki-Ebor, E.E.; Afonya, T.C.A.; Oyaide, S.M 130

Influence of p-Lactam Antibiotics, Fosfomycin and Vancomycin on the Adherence (Hem agglutination) of Escherichia coli-Containing Different Adhesins

Klein, U.; Pawelzik, M.; Opferkuch, W 138

Experimental Chemotherapy

Measurement of Adenine Uptake as an in vitro Screen for Antitrichomonal Agents

Meingassner, J.G.; Heyworth, P.G.; Havelec, L 146

Acyclic Pyrimidine Nucleoside Analogues: Influence on Growth of L5178y Mouse Lymphoma

Cells and Antiherpes Activity in KB Cells Allen, L.B.; Schroder, H.C; Zahn, R.K.; Stoss, P.;

Maidhof, A.; Miiller, W.E.G. ... 151

Effects of Mechlorethamine on Lysosomal Enzyme Release from HeLa and 3T3 Cells

Kavli, G.; Andersen, O.K.; Volden, G 160

Erratum $\quad 168$

Announcement $\quad 168$

No. 3 Pharmacology

Mezlocillin Concentrations in Human Aqueous Humour after Intravenous and Subconjunc

tival Administration

Behrens-Baumann, W.; Ansorg, R 169

Microbiology

Augmentation Effect of Clavulanic Acid with Penicillin, Cephalothin and Ticarcillin against

Bacteroides fragilis

Bansal, M.B.; Chuah, S.-K.; Oryema-Lalobo, M.; Thadepalli, H 173

Influence of Aminoglycoside Usage on Susceptibilities. Influence of Aminoglycoside Usage

on Susceptibilities

Flournoy, D.J 178

Contents

$\mathrm{V}$

The Activity of Ceftazidime Compared with Those of Aztreonam, Newer Cephalosporins 
and Sch 29482 against Nonfermentative Gram-Negative Bacilli

Schell, R.F.; Francisco, M.; Bihl, J.A.; LeFrock, J.L 181

In vitro Synergistic Activity of Some Chinolinic Compounds Combined with P-Lactam

Antibiotics against Gram-Positive and Gram-Negative Clinical Isolates

Ravagnan, G.; Piccolomini, R.; Speciale, A.M.; Russo, G.; Renzini, G

Inhibitory Activity of Cefpiramide on p-Lactamase

Fu, K.P.; McCloud, S.; Gregory, F.J.; Hung, P.P 200

Increased Minimum Inhibitory Concentrations with Anaerobiasis for Tobramycin, Genta-

micin, and Amikacin, Compared to Latamoxef, Piperacillin, Chloramphenicol, and

Clindamycin

Tack, K.J.; Sabath, L.D 204

Susceptibility of Candida spp. of Clinical Origin to Lucknomycin, a New Polyenic Antibiotic

Sousa, A.S.; Gomez-Criado, C; Baquero, F 211

Experimental Chemotherapy

Adverse Effect of Cyclophosphamide at Moderate Dose in Combination with Standard

Drugs on Intraperitoneally Implanted Lewis Lung Carcinoma in Mice

Furusawa, E.; Furusawa, S 216

Effect of Hydrocortisone and BCNU on Long-Term Murine Bone Marrow Cultures

Horikoshi, A.; Murphy, M.J., Jr 223

Clinical Report

Prophylaxis and Treatment of Anaerobic Infections following Caesarean Section with

Tinidazole

Karhunen, M.; Koskela, O.; Teisala, K.; Suikkari, A.-M.; Mattila, J228

No. 4 Pharmacology

Comparative Pharmacokinetics of Ceftriaxone after Subcutaneous and Intravenous Administration

Borner, K.; Lode, H.; Hampel, B.; Pfeuffer, M.; Koeppe, P 237

Affinity of Carumonam for Penicillin-Binding Proteins

Then, R.L.; Kohl, 1246

Penetration of Latamoxef, Cefoperazone and Piperacillin into the Sputum of Patients with Cystic Fibrosis

Laferriere, C; Stutman, H.R.; Marks, M.I.; Kramer, J.; Flux, M 255

Pharmacokinetics of Lymecycline and Doxycycline in Serum and Suction Blister Fluid

Schreiner, A.; Digranes, A 261

Biliary Elimination of Apalcillin in Cholecystectomized Patients

Harnoss, B.M.; Harnoss, CM.; Borner, K.; Lode, H; Koeppe, P 266

Microbiology

The Interaction of Beta-Lactam Compounds with Chromosomally Mediated Enzymes:

Relations to the Molecular Structure

Cullmann, W 272

Ro 17-2301: In vitro Comparison with Aztreonam, Imipenem, Ceftazidime, Cefotaxime and Netilmicin

Digranes, A.; Dibb, W.L.; Benonisen, E.; Salveson, A 279

Contents

Unstable L-Form of Proteus mirabilis Induced by Fosfomycin

Schmid, E.N 286 
Comparative Antibacterial Activities of New P-Lactam Antibiotics against Pseudomonas aeruginosa

Fernandes, C.J.; Stevens, D.A.; Ackerman, V.P 292

Experimental Chemotherapy

Relative Antibacterial Efficacy of Clindamycin and Metronidazole against Bacteroides

fragilis in vitro and in Experimentally Infected Mice

Dijkmans, B.A.C.; Vaishnav, J.; Mattie, H 297

Efficacy of Imipenem in Experimental Group B Streptococcal Bacteremia and Meningitis

Kim, K.S 304

Synergistic Antiviral Effects of Acyclovir and Vidarabine on Herpes simplex Infection in Newborn Mice

Karim, M.R.; Marks, M.I.; Benton, D.C.; Rollerson, W 310

Variation in Microbial Survival and Growth in Intravenous Fluids

Rawal, B.D.; Nahata, M.C 318

Clinical Report

Rifampicin for Non-Tuberculous Infections?

Griineberg, R.N.; Emmerson, A.M.; Cremer, A.W.F324

Pharmacology

Clinical Pharmacokinetics of Amoxycillin and Theophylline during Cotreatment with Both Medicaments

Jonkman, J.H.G.; Boon, W.J.V. van der; Schoenmaker, R.; Holtkamp, A.H.; Hempe-

nius, J 329

Cefotaxime Aminoglycoside Interactions

Pierce, M.A.; Elliott, A.M.; Cobbs, C.G 336

Microbiology

Activity of Nine Antibacterial Agents on Penicillinase- and Nonpenicillinase-Producing Neisseria gonorrhoeae Isolated from Clinical Specimens Obtained in Northern Norway

Melby, K.; Storvold, G.; Leinslie, T.; Falk, E.S 346

Experimental Chemotherapy

Amikacin + Ceftazidime Therapy of Experimental Right-Sided Pseudomonas aeruginosa

Endocarditis in Rabbits

Bayer, A.S.; Lam, K.; Norman, D.; Kim, K.S.; Morrison, J.0 351

Antiandrogen and Antineoplastic Effects of a Novel Drug, CPC10997

Ford, L.C.; Kasha, W.; Chang, N.H.C.; DeLange, R.J 362

Murine Model for Therapy of Listeriosis in the Compromised Host. IV. Cotrimoxazole

Kawaler, B.; Hof, H 366

Multiple Drug-Resistant Corynebacteriaceae: in vitro and in vivo (Murine) Studies

Traub, W.H 372

Inhibition of Cell Proliferation by a Synthetic C-Nucleoside (EIT)

Fuente, M. de la; Fernandez, M.M.; Pena, J 383

Synergism between Gentamicin and Mitomycin C in Staphylococcal Infections in Mice

Jacobs, J.Y.; Wax, Y.; Michel, J.; Sacks, T 389

Contents VII

Correlation of Susceptibility Test Results in vitro with Response in vivo: Ketoconazole

Therapy in a Systemic Candidiasis Model

Polak, A.; Odds, F.C.; Ludin, E.; Scholer, H.J 
No. 6 Pharmacology

Pharmacokinetics of Brodimoprim in Serum and Skin Blister Fluid

Kalager, T.; Digranes, A.; Salveson, A.; Bergan, T 405

Pharmacokinetics of Ceftazidime in Patients with Renal Insufficiency and in Undergoing Hemodialysis

Ohkawa, M.; Nakashima, T.; Shoda, R.; Ikeda, A.; Orito, M.; Sawaki, M.; Sugata, T.;

Shimamura, M.; Hirano, S.; Okumura, K 410

Pharmacokinetic Studies of Azlocillin and Piperacillin during Late Pregnancy

Voigt, R.; Schroder, S.; Peiker, G 417

Microbiology

Bactericidal Activity and Induction of Cell Volume Alterations of Cephalosporins in

Escherichia coli

Schulz, E.; Klitzing, L. von; Sack, K.; Marre, R 425

Trends in Bacterial Susceptibility to Antimicrobial Agents

Lane, M.M.; Parker, D.E.; Flournoy, D.J 433

Antibacterial Properties of Carumonam (Ro 17-2301, AMA-1080), a New Sulfonated

Monocyclic (3-Lactam Antibiotic

Angehrn, P 440

Aztreonam: Correlation between Disk Diffusion and Agar Plate Dilutions Susceptibility

Tests

Toma, E.C.; Morisset, R.; Phaneuf, D.; Poisson, M 451

In vitro Activity of Ciprofloxacin against Pediatric Pathogens

Weber, A.H.; Scribner, R.K.; Marks, M.I 456

In vitro Activities of Ciprofloxacin, Ofloxacin, Norfloxacin and Rosoxacin Compared with

Cinoxacin and Trimethoprim

Digranes, A.; Dibb, W.L.; Benonisen, E 466

Experimental Chemotherapy

Antitumour Activity of Chlorimidazine on Transplantable Mouse Tumour Systems

Mircheva, J.J.; Pantev, T.P 472

Clinical Report

Prophylactic Single-Dose Co-trimoxazole for Prevention of Urinary Tract Infection after Abdominal Hysterectomy

Jaffe, R.; Altaras, M.; Fejgin, M.; Ben-Aderet, N 476

Book Review 480

Author Index 481

Subject Index 483 